\author{
Andrea Bencsik, \\ Professor, J. Selye University, Slovakia \\ Professor, University of Pannonia, Hungary \\ (iD) ORCID ID, 0000-0001-8204-3706 \\ e-mail:bencsika@ujs.sk \\ Bence Csinger, \\ J. Selye University, Slovakia \\ (iD) ORCID ID, 0000-0002-1348-4660 \\ e-mail: 122474@student.uis.sk
}

Correspondence author: 122474@student.ujs.sk

\title{
INNOVATIONS IN HUMAN RESOURCES MANAGEMENT OF HIGHER EDUCATION INSTITUTIONS: TECHNOSTRESS FACTORS
}

Abstract. The study on technostress is very significant in today's knowledge-based society. Technostress, which has developed due to the information-technology explosion over the past decade, plays an increasingly critical role in people's lives. The study shows that the flood of information and the increased use of more technological tools could cause frustration, anxiety, and fear. The timeliness of the topic lies in the fact that if society does not pay attention to this new kind of public disease now, it would have a negative impact on people's health, quality of life, and efficiency at the corporate level. The study's theoretical background was analyzed by reviewing the international scientific literature available on the subject of technostress. The research aims to explore the relationship between factors belonging to the group of technostress creators concerning Hungarian higher educational institutions. In the study, the authors set up a research model to explore the relationship between technostress creators, which was examined using a quantitative questionnaire query. The study covered 237 employees working in higher education in Hungary. The results were analyzed in the SPSS 22 statistical program. During the evaluation, linear regression analysis was used to explore these relationships. The results demonstrated that the five components of technostress are technooverload, techno-invasion, techno-complexity, techno-insecurity, and techno-uncertainty. These frequently interact with each other in higher education. The results of the study point to the fact that the five components of technostress embodied in higher education institutions are interrelated, which, when appearing in the lives of university lecturers, contributes to the increase in the level of technostress. The research results could be useful for all higher education institutions in terms of what factors they should place great emphasis on to reduce or prevent technostress.

Keywords: higher education institution, information flood, public disease, technological impact, university lecturers.

Introduction. Higher education institutions worldwide are keen to innovate learning and teaching through new information and communication technologies (ICT), such as online courses and support for technology learning. ICTs could be major contributors to improving learning and teaching. In the future, there will be an increasing need for teachers in higher education to have the skills and knowledge needed to use ICT effectively. However, changes in learning, teaching processes, the role of educators, educational practice, and work requirements by technology could be stressful for educators as they are forced to devote more time to adapt to the changes. As a result, university educators are at greater risk for technostress, an adaptation problem in which users are unable to cope with new technology and the requirements associated with their use. The previous study (Jena, 2015) revealed that technostress could have some negative consequences in people's personal lives, including depression and concentration problems and in their professional lives, such as decreased job satisfaction, declining organizational commitment, and lower work performance. Research on technostress has mostly been conducted in the

Cite as: Bencsik, A., \& Csinger, B. (2021). Innovations in Human Resources Management of Higher Education Institutions: Technostress Factors. Marketing and Management of Innovations, 4, 55-67. http://doi.org/10.21272/mmi.2021.4-05 
A., Bencsik, B., Csinger. Innovations in Human Resources Management of Higher Education Institutions: Technostress Factors

industrial and public sectors, with little evidence in education. Educators play a key role in the successful acquisition of technology in education. However, ever-evolving ICTs are transforming learning and teaching and putting great pressure on educators to work faster and constantly update their knowledge and skills. Their knowledge of these information and communication technologies, their attitudes towards ICT, and the experience gained in their work are essential for integrating technology. The study of technostress experienced by university lecturers is of critical importance to the maintenance and wellbeing of university teachers. Besides, it contributes to the digitization of higher education (Li and Wang, 2020). New technologies could potentially benefit students. However, it could put increased pressure on university faculty, who are often less able to apply these technologies but still have to adapt to university requirements in workplace technologies, which are affected significantly by the rapid change and development of ICTs. Technostress is related not only to the information and communication technology that causes it but also to organizations that set requirements for the use of ICTs and the staff of organizations that often influence individuals 'use of ICT. Technostress caused by several dimensions of the university environment can negatively affect the work performance of university faculty, which can lead to burnout at work and even an intention to resign (Li and Wang, 2019).

Digitizing education could be a daunting task for educators, as digitizing work requires learning new things and applying new technologies. It requires a special effort and leads to a greater workload and time. Thus, stress can also be defined as an indicator of learning. Digitizing the work could force the instructor to change his or her way of teaching. In addition, technostress can also occur in situations where the educator feels compelled to use ICTs in education, even though this contradicts his or her personal teaching preferences (Syvanen et al., 2016). Nowadays, employees need to master the management of more and more technological tools, which results in increased frustration, anxiety and feelings of stress, regardless of age. The research is motivated mainly by the fact that the occurrence of the topic in education is no less significant than in the business environment. Based on this, the study aims to examine how the factors belonging to the group of each technostress creator relates to each other in higher education.

As a first step, a general overview of the new public disease was presented, followed by a comparative analysis of previous research on the topic. In the last part of the literature review, in addition to presenting the role of technostress in higher education, the research question and the authors' hypotheses were formulated. In the practical part of the study, the relationship between the five technostress creators in higher education was presented. The study rests on a survey of 237 employees of Hungarian institutions.

Literature Review. Brod (1984) said that technostress manifests itself in two distinct and coherent ways: in the struggle for computer adoption and a more specialized form of over-identification with computer technology. In 1992, Kupersmith concluded that the Internet was probably one of the major causes of technostress. The maintenance and updating of many new information sites did not meet the design standard. Facing Information overload is a real problem. Five years later, Arnetz and Wiholm (2006) noted that most jobs in the 21st century would require some technological interaction. In their view, computer interaction is, on the one hand, inevitable and, on the other hand, contributes greatly to the development of technostress, which could lead to work and health problems that later result in absenteeism and declining productivity. Kupersmith (2003) found that information overload, network problems, security issues, and constant computer hardware and software upgrades were the main causes of technostress. Common symptoms include isolation, feelings of frustration, and negative attitudes toward new computer technologies. Brillhart (2004) noted that stress was an important issue for organizations. Besides, employers need to address it for their employees to be productive in the workplace. In his view, anxiety and tension could also arise from a user's inability to use the technology, resulting in a disadvantage to other employees (Sareen, 2019). Tu et al. (2005) stated that the widespread use of the Internet and information technology in China posed serious challenges to the potential effectiveness of technostress on users' mental health and productivity at work; both for everyday users and IT professionals (Tu et al., 2005). Modern technologies require an almost constant connection. As a result, people feel 
ceaselessly on call and gain more information than they could process efficiently. This kind of technological complexity leads to stress. Tarafdar et al. (2017) defined technostress as one of an individual's attempts and struggles to address ever-evolving technologies and the changing cognitive and societal demands associated with their use (Ragu-Nathan et al., 2007). The definition by Tarafdar et al. (2010) already includes emerging applications, constant connectivity, information overload, regular system updates, constant uncertainty, a continuous re-learning process, stress due to job insecurities, and organizational use of information and communication technologies, technical problems (Ragu-Nathan et al., 2011).

Thomée et al. (2007) found that technostress could cause depression and sleep problems that affect many other aspects of life, such as privacy (Sareen, 2019). Al-Fudair and Mellar (2008) researched the field of education. Their study concluded that technostress has been significantly present in the lives of educators over the past decade due to the technologies used in schools and their constant change. Recognizing that technology could have a detrimental effect on teachers, schools have put in place processes that help reduce technostress. These include an increase in technology training, practicing new technologies before using them, and a change in educational style (Al-Fudahir and Mellar, 2008).

Tarafdar et al. (2008) identified three important characteristics of the technological environment. Managers and employees are increasingly dependent on information and communication technologies (e.g., personal computers, enterprise applications) whose software and hardware are constantly updated. Furthermore, due to the increasing sophistication of ICTs, there are often significant differences between the technological skills required and the actual knowledge of employees and managers. The third feature is that modern ICTs have changed the work environment and culture. E-mail, electronic scheduling, and video conferencing make it easier to organize flexible work schedules and telecommuting. Still, this kind of change could lead to an increase in multitasking, social isolation, and abstraction of work. These three characteristics represent a fundamental shift in an individual's workplace interaction. Although information and communication technologies have liberating effects that relieve workers of repetitive tasks, they also require new work patterns and more technological skills (Ragu-Nathan et al., 2008). Tarafdar et al. (2007) identified five technostress creators, which are as follows:

- techno overload: a situation where ICT users are forced to work faster and for longer;

- techno-invasion: a situation where ICT users feel they need to be available at all times;

- techno-complexity: a condition in which ICT users feel that their skills are inadequate due to the complexity of information and communication technology;

- techno insecurity: a situation where ICT users feel threatened by losing their job or being replaced by another person with higher technological skills;

- techno-uncertainty: a situation where ICT users feel insecure due to technology's constant change and development (Ahmad et al., 2012).

In the next part of the study, a comparative analysis of previous research on the topic was presented, which helped form a comprehensive picture of the current situation. Table 1 illustrates the results of the secondary data collection.

Based on the comparative analysis, it can be stated that technostress creators undermine innovation and negatively affect users 'perceived work performance, satisfaction, and commitment. Information and communication technology supports higher education in many ways in terms of teaching and learning. Since the early 1970s, the ways in which ICTs are used to support learning and teaching, along with Internet technology, have constantly been changing. Collaborating with technology has always been a challenge for educators, especially due to the tension arising from the use of technology. The higher education system is heavily influenced by technological developments, as a result of which those involved in higher education need to find ways to adapt to technological changes.

Table 1. Research findings from studies on technostress

\begin{tabular}{cccc}
\hline $\begin{array}{c}\text { Technostress } \\
\text { research }\end{array}$ & Research results & $\begin{array}{c}\text { Research } \\
\text { method }\end{array}$ & $\begin{array}{c}\text { Research } \\
\text { subjects }\end{array}$ \\
\hline
\end{tabular}


A., Bencsik, B., Csinger. Innovations in Human Resources Management of Higher Education Institutions: Technostress Factors

\begin{tabular}{|c|c|c|c|}
\hline 1 & 2 & 3 & 4 \\
\hline $\begin{array}{l}\text { Tarafdar, Tu } \\
\text { and Ragu- } \\
\text { Nathan (2010) }\end{array}$ & $\begin{array}{l}\text { 1. Technostress creators damage innovation and } \\
\text { productivity. } \\
\text { 2. Mechanisms to facilitate user involvement } \\
\text { reduce the factors that create technostress. } \\
\text { 3. Organizational mechanisms that support } \\
\text { innovation reduce the factors that create } \\
\text { technostress. } \\
\text { 4. Technostress factors negatively affect the } \\
\text { satisfaction of ICT users with the applications and } \\
\text { systems they use and their ability to use them } \\
\text { productively and innovatively in the context of } \\
\text { performance outcomes and ICT-mediated tasks. } \\
5 \text {. Technostress also produces negative results in } \\
\text { the field of end-user computing. } \\
6 \text {. Innovation, user-to-user communication, and a } \\
\text { supportive environment reinforce mechanisms to } \\
\text { reduce technostress. }\end{array}$ & $\begin{array}{l}\text { Questionnaire } \\
\text { query }\end{array}$ & $\begin{array}{l}\text { Investigation of } \\
\text { two public sector } \\
\text { organizations in } \\
\text { the Midwestern } \\
\text { United States - } \\
264 \text { questionnaires } \\
\text { sent out - } 233 \\
\text { responses } \\
\text { received }\end{array}$ \\
\hline Jena (2015) & $\begin{array}{l}\text { 1. The creators of technostress negatively affect job } \\
\text { satisfaction and organizational commitment. } \\
2 \text {. There is a significant relationship between the } \\
\text { constituents of technostress, negative affectivity, and } \\
\text { technology-supported performance. } \\
\text { 3. Technostress inhibitors (inhibitors) negatively } \\
\text { affect the constituents of technostress and positively } \\
\text { affect job satisfaction, organizational commitment, } \\
\text { and technology-supported performance. }\end{array}$ & $\begin{array}{c}\text { Questionnaire } \\
\text { query }\end{array}$ & $\begin{array}{c}\text { Research } \\
\text { subjects: Survey of } \\
\text { academics from } \\
\text { Indian universities } \\
\text { and colleges - } 400 \\
\text { questionnaires } \\
\text { sent out - } 224 \\
\text { responses } \\
\text { received - } 216 \\
\text { were suitable }\end{array}$ \\
\hline $\begin{array}{l}\text { Chen and } \\
\text { Muthitacharoen } \\
(2016)\end{array}$ & $\begin{array}{l}\text { 1. Technostress has a significant negative impact } \\
\text { on users 'perceived work performance. } \\
\text { 2. Technostress undermines perceived job } \\
\text { performance, satisfaction, and attitudes toward } \\
\text { technology. } \\
\text { 3. Technostress mediates perceived work } \\
\text { performance on IT-centric factors. }\end{array}$ & $\begin{array}{l}\text { Questionnaire } \\
\text { query }\end{array}$ & $\begin{array}{c}\text { Investigation of } \\
1,500 \text { employees } \\
\text { in } 64 \text { companies in } \\
\text { China - } 221 \\
\text { responses were } \\
\text { received. }\end{array}$ \\
\hline $\begin{array}{l}\text { Saunders, } \\
\text { Wiener, Klett } \\
\text { and Sprenger } \\
\text { (2017) }\end{array}$ & 1. Age is not related to ICT-related congestion. & $\begin{array}{l}\text { Questionnaire } \\
\text { query }\end{array}$ & $\begin{array}{c}\text { Respondents to } \\
\text { the survey were } \\
\text { recruited via e- } \\
\text { mail, in person, } \\
\text { letter of invitation, } \\
\text { and through social } \\
\text { media - reached } \\
1377 \text { people - } \\
1004 \text { responses } \\
\text { were returned }\end{array}$ \\
\hline
\end{tabular}

Continued Table 1

$1 \quad 2 \quad 3 \quad 4$


A., Bencsik, B., Csinger. Innovations in Human Resources Management of Higher Education Institutions: Technostress Factors

\begin{tabular}{|c|c|c|c|}
\hline & \multirow[b]{2}{*}{$\begin{array}{l}\text { Random sampling - } \\
\text { reaching } 400 \\
\text { individuals - } \\
\text { returned } 346 \\
\text { responses }\end{array}$} \\
\hline $\begin{array}{l}\text { Boonjing and } \\
\text { Chanvarasuth } \\
\text { (2017) }\end{array}$ & $\begin{array}{l}\text { technostress. } \\
\text { 2. Technostress is positively related to physical } \\
\text { and psychological health. } \\
\text { 3. Technostress has a negative effect on } \\
\text { satisfaction, performance, and thus work efficiency. }\end{array}$ & $\begin{array}{c}\text { Questionnaire } \\
\text { query }\end{array}$ & \\
\hline $\begin{array}{l}\text { Al-Ansari and } \\
\text { Aalshare } \\
\text { (2019) }\end{array}$ & $\begin{array}{l}\text { 1. The creators of technostress negatively affect } \\
\text { job satisfaction. } \\
\text { 2. Technostress inhibitors have a positive effect on } \\
\text { job satisfaction. }\end{array}$ & $\begin{array}{l}\text { Questionnaire } \\
\text { query }\end{array}$ & $\begin{array}{l}\text { Random sampling - } \\
410 \text { responses were } \\
\text { returned - } 401 \text { were } \\
\text { suitable. }\end{array}$ \\
\hline $\begin{array}{l}\text { Pirkkalainen, } \\
\text { Salo and } \\
\text { Tarafdar } \\
\text { (2019) }\end{array}$ & $\begin{array}{l}\text { 1. Technostress creators are negatively related to } \\
\text { IT-enabled productivity, so the higher the level of } \\
\text { technostress constituents, the lower the level of } \\
\text { IT-capable productivity. } \\
\text { 2. IT isolation reduces the relationship between } \\
\text { technostress creators and IT-based productivity, } \\
\text { so the higher the level of IT isolation, the less } \\
\text { negative the relationship between technostress } \\
\text { creators and IT-based productivity. }\end{array}$ & $\begin{array}{l}\text { Questionnaire } \\
\text { query }\end{array}$ & $\begin{array}{l}\text { Full-time IT users - } \\
1,049 \text { responses } \\
\text { were returned - } 846 \\
\text { were eligible }\end{array}$ \\
\hline $\begin{array}{l}\text { Maier, } \\
\text { Laumer, Wirth } \\
\text { and Weitzel } \\
\text { (2019) }\end{array}$ & $\begin{array}{l}\text { 1. The higher an individual's neurotic, the higher } \\
\text { the techno-stressors. } \\
\text { 2. The higher the personal innovativeness in IT, } \\
\text { the lower the techno-stressors. } \\
\text { 3. The higher the IT awareness, the lower the } \\
\text { techno-stressors. } \\
\text { 4. The higher the techno-stressors, the higher the }\end{array}$ & $\begin{array}{l}\text { Questionnaire } \\
\text { query }\end{array}$ & $\begin{array}{l}\text { Sample 1: } \\
\text { Employees of a } \\
\text { German organization } \\
\text { Sampling 2: } \\
\text { Individuals from the } \\
\text { USA participated. }\end{array}$ \\
\hline & $\begin{array}{l}\text { probability of burnout at work. } \\
5 \text {. The higher the user participation, the lower the } \\
\text { techno-stressors. } \\
\text { 1. Techno overload is significantly related to } \\
\text { gender, age group, and work activity. }\end{array}$ & & $\begin{array}{l}\text { The final data set } \\
\text { contained } 408 \\
\text { evaluable responses. }\end{array}$ \\
\hline $\begin{array}{l}\text { La Torre, De } \\
\text { Leonardis and } \\
\text { Chiappetta } \\
\text { (2020) }\end{array}$ & $\begin{array}{l}\text { 2. Techno-invasion is significantly related to } \\
\text { gender, education, and techno-complexity is } \\
\text { significantly related to marital status. } \\
\text { 3. Techno-complexity is also significantly related } \\
\text { to age, marital status, work, and year of } \\
\text { employment. }\end{array}$ & $\begin{array}{c}\text { Questionnaire } \\
\text { query }\end{array}$ & $\begin{array}{l}\text { Research subjects: } \\
\text { persons between } 16 \\
\text { and } 65 \text { years of age } \\
\text { The study sample: } \\
313 \text { individuals. }\end{array}$ \\
\hline & $\begin{array}{l}\text { 4. There was no significant correlation with any of } \\
\text { the factors listed earlier in terms of technical } \\
\text { uncertainty. }\end{array}$ & & \\
\hline
\end{tabular}

Sources: developed by the authors based on (Tarafdar et al., 2010; Jena, 2015; Chen and Muthitacharoen, 2016; Saunders et al., 2017; Boonjing and Chanvarasuth, 2017; Al-Ansari and Aalshare, 2019; Pirkkalainen et al., 2019; Maier et al., 2019; La Torre et al., 2020).

. Instructors spend a tremendous amount of time with technology to prepare students for the knowledge needed to adapt and apply the latest technologies. In the 21st century, the importance and usability of technology in collaborative learning create fear and stress for many educators. For university professors, continuous technological advancement results in work overload, changes in work patterns, continuous improvement in technological knowledge and skills, and higher demands on performance and productivity (Jena, 2015). In this context, educators 'efforts to integrate technology into educational processes are influenced by external factors such as communication, collaboration with colleagues, and the fact that they do not receive a return on their efforts or could not meet all expectations. It manifests 
A., Bencsik, B., Csinger. Innovations in Human Resources Management of Higher Education Institutions: Technostress Factors

itself as technostress. Joo et al. (2006) concluded that increasing the technological competence of educators reduces the stress associated with computer use (Ozgur, 2020). Information and communication technologies are evolving at an unprecedented rate, with the result that it is increasingly likely that technostress, although generated in the workplace, is intertwined with the non-work life of individuals (Coklar et al., 2016). Educators' technological skills, knowledge, time, workload, and attitude to technology significantly influence technology integration in education. These factors include technostress. Higher workloads for users with the knowledge that work could be done more easily and quickly with advanced technology could also be stressful. In addition, lack of professional development and practice, limited training and resources, overload, and low human interaction are also among the factors that contribute to the development of technostress in educators. However, it is important to mention hardware failures, computer failures, the growing expectations of computer literacy, and the complexity of computer terminology as stressors. Technostress is an important issue in higher education. Instructors experience technostress in particular during integrating new technologies, which is mainly due to the continuous development of digital technologies. The constant technological integration pressure of institutions and society due to lack of knowledge and support also causes technostress among educator (Coklar et al., 2017).

Methodology and research methods. Based on the study's literature review, the main research question is How do the factors of technostress creators relate to each other in higher education?

Considering the literature review, the authors created a research model (Figure 1) that depicts the correlations of the hypotheses and forms the starting point of the questionnaire research:

$\mathrm{H} 1$ The coercive effect of technology is significantly related to the complexity of understanding the new technology.

$\mathrm{H} 2$ The strong influence of technology on personal life as well as the sacrifice of leisure time are significantly two-way.

$\mathrm{H} 3$ The time required to master new technologies is significantly related to the strong influence of technology on personal life.

H4 Lack of time, related to the development of technological skills, is significantly related to the sacrifice of leisure time related to the development of technological skills.

H5 Continuous technological development within the organization and frequent computer network upgrades are significantly related.

The model examines the relationship between the factors underlying the five technostress components. The practical research is based on a quantitative survey. In 2020, the authors examined the effects of technostress among those working in economics training in Hungarian higher education institutions with the help of a questionnaire. The questionnaire was sent in the form of «direct mail» after a test phase. The questionnaire was available to all employees and was completed online in an anonymous form. It contained 48 questions. The questions were divided into five research question groups (Table 2).

The willingness to participate was not very high. Of all the questionnaires sent out, only about $11 \%$ were returned. The number of completed and evaluable responses that could be used in the analysis was 237. The evaluation was performed using SPSS 22 program. In examining the hypotheses, the authors used multiple regression statistical methods, including path analysis. A significance level of $5 \%$ was determined during the evaluation. During the analysis, the dependent and independent variables were identified. Those were classified into the appropriate places using the program. The next step was to set the confidence intervals to $95 \%$. 
A., Bencsik, B., Csinger. Innovations in Human Resources Management of Higher Education Institutions: Technostress Factors

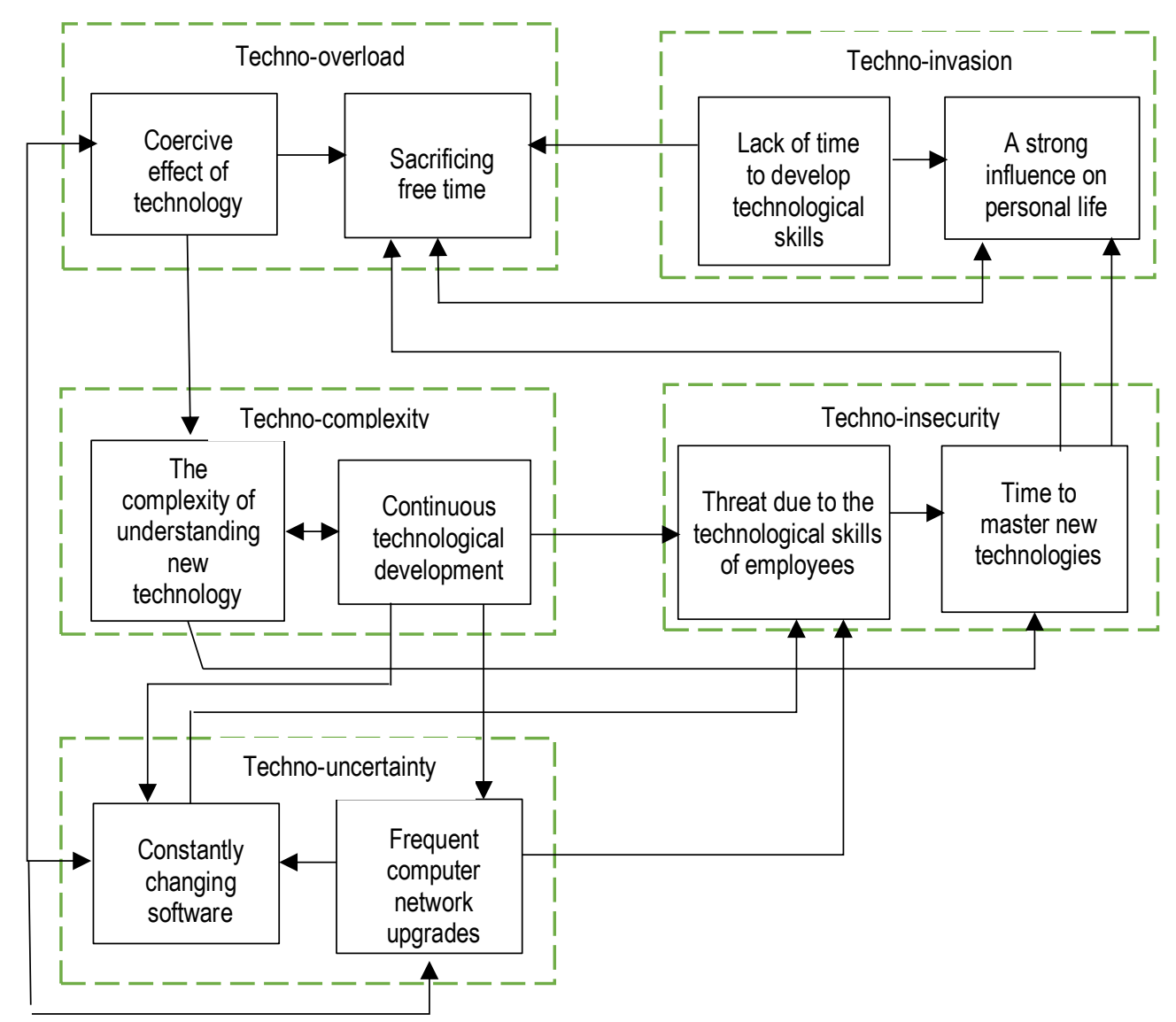

Figure 1. The research model

Note: The arrows in Figure 1 illustrate the hypothetical relationships and hypotheses.

Sources: developed by the authors.

Table 2. Structure of question groups

\begin{tabular}{ccccc}
\hline $\begin{array}{c}\text { Question } \\
\text { group 1 }\end{array}$ & $\begin{array}{c}\text { Question } \\
\text { group 2 }\end{array}$ & $\begin{array}{c}\text { Question } \\
\text { group 3 }\end{array}$ & $\begin{array}{c}\text { Question } \\
\text { group 4 }\end{array}$ & $\begin{array}{c}\text { Question } \\
\text { group 5 }\end{array}$ \\
\hline Job title, schedule, work & $\begin{array}{c}\text { Treatment, } \\
\text { security, } \\
\text { schedivation, } \\
\text { respect, etc. }\end{array}$ & $\begin{array}{c}\text { Provision of } \\
\text { information, } \\
\text { relationship with } \\
\text { technology, } \\
\text { institutional } \\
\text { workplace support }\end{array}$ & $\begin{array}{c}\text { Own experience } \\
\text { and experience in } \\
\text { connection with } \\
\text { ICT technology } \\
\text { and tools }\end{array}$ & Demography \\
& & & & \\
\hline
\end{tabular}

Sources: developed by the authors.

The authors set the $Y$-axis to ZRESID (Standardized residuals) and the $X$-axis to ZPRED (Standardized predicted values) and added the option to create a histogram. After performing these processes, the authors obtained the results (Table 3 ). 
A., Bencsik, B., Csinger. Innovations in Human Resources Management of Higher Education Institutions: Technostress Factors

In the research model, a back-and-forth relationship was hypothesized between the sacrifice of leisure time and the powerful influence of technology on personal life. In this case, two analyses were performed: 1) the sacrifice of leisure time; 2) the strong influence on personal life was defined as a dependent variable.

Results. The authors asked the research subjects what they thought about certain statements related to the five technostress constituents. They had to answer this question on a five-point Likert Scale, where each value of one meant strongly disagree, while a value of five meant strongly agree. After that, the focus shifted to their own experiences. The authors were also curious about their impressions of their jobs concerning certain allegations. As before, in this case, they had to answer on a five-point scale. For each value up to several times a year, six was never the definition.

In the analysis, the authors examined whether each technostress component influenced each other and, if so, in what direction. The effects of techno-overload, techno-invasion, techno-complexity, technouncertainty, and techno-unpredictability were analyzed using pathway analysis. The indicators used to measure techno overload in the present study were the coercive effect of technology and the sacrifice of leisure time. In the case of techno-invasion, the lack of time for the development of technological skills and the strong influence on personal life were examined. The following factors were analyzed within technocomplexity: the complexity of understanding the new technology and continuous technological development. In measuring techno-uncertainty, the threat posed by employees and the time taken to master new technologies were examined. The last component of technostress, techno-unpredictability, the constantly changing software, and the frequent computer network upgrades were analyzed. The relationships of the study models were verified by linear regression (Table 3 ). The table includes only significant relationships.

Table 3. Results of linear regression

\begin{tabular}{|c|c|c|c|c|c|c|}
\hline \multicolumn{2}{|c|}{ Parameters } & \multicolumn{4}{|c|}{ Model summary } & \multirow{2}{*}{$\begin{array}{c}\begin{array}{c}\text { Standardized } \\
\text { coefficient }\end{array} \\
\beta \\
\end{array}$} \\
\hline Dependent & Independent & $r^{2}$ & $\mathbf{F}$ & df & Sign. & \\
\hline 1 & 2 & 3 & 4 & 5 & 6 & 7 \\
\hline Sacrificing free time & $\begin{array}{l}\text { Coercive effect of } \\
\text { technology }\end{array}$ & ,105 & 27,563 & 1 &, 000 & ,324 \\
\hline Sacrificing free time & $\begin{array}{l}\text { Lack of time to } \\
\text { develop } \\
\text { technological } \\
\text { skills }\end{array}$ &, 067 & 16,929 & 1 &, 000 & ,259 \\
\hline Sacrificing free time & $\begin{array}{l}\text { Strong influence } \\
\text { on personal life }\end{array}$ & ,220 & 66,451 & 1 &, 000 & ,470 \\
\hline Sacrificing free time & $\begin{array}{l}\text { Time to master } \\
\text { new technologies }\end{array}$ &, 074 & 18,739 & 1 & ,000 & 272, \\
\hline $\begin{array}{l}\text { Strong influence on } \\
\text { personal life }\end{array}$ & $\begin{array}{l}\text { Lack of time to } \\
\text { develop } \\
\text { technological } \\
\text { skills }\end{array}$ & ,149 & 41,223 & 1 &, 000 & ,386 \\
\hline $\begin{array}{l}\text { Strong influence on } \\
\text { personal life }\end{array}$ & $\begin{array}{l}\text { Sacrificing free } \\
\text { time }\end{array}$ & ,220 & 66,451 & 1 &, 000 & ,470 \\
\hline $\begin{array}{l}\text { Strong influence on } \\
\text { personal life }\end{array}$ & $\begin{array}{l}\text { Time to master } \\
\text { new technologies }\end{array}$ & ,095 & 24,671 & 1 &, 000 & ,308 \\
\hline
\end{tabular}


A., Bencsik, B., Csinger. Innovations in Human Resources Management of Higher Education Institutions: Technostress Factors

\begin{tabular}{|c|c|c|c|c|c|c|}
\hline & & & & & \multicolumn{2}{|c|}{ Continued Table 3} \\
\hline 1 & 2 & 3 & 4 & 5 & 6 & 7 \\
\hline $\begin{array}{l}\text { The complexity of } \\
\text { understanding new } \\
\text { technology }\end{array}$ & $\begin{array}{l}\text { Coercive effect of } \\
\text { technology }\end{array}$ & ,227 & 68,891 & 1 &, 000 & ,476 \\
\hline $\begin{array}{l}\text { Time to master new } \\
\text { technologies }\end{array}$ & $\begin{array}{l}\text { Threat due to the } \\
\text { technological } \\
\text { skills of } \\
\text { employees }\end{array}$ & ,111 & 29,481 & 1 &, 000 & ,334 \\
\hline $\begin{array}{c}\text { Constantly changing } \\
\text { software }\end{array}$ & $\begin{array}{l}\text { Continuous } \\
\text { technological } \\
\text { development }\end{array}$ & ,254 & 79,806 & 1 &, 000 &, 503 \\
\hline $\begin{array}{c}\text { Constantly changing } \\
\text { software }\end{array}$ & $\begin{array}{c}\text { Frequent } \\
\text { computer network } \\
\text { upgrades }\end{array}$ & ,352 & 127,778 & 1 &, 000 &, 593 \\
\hline $\begin{array}{l}\text { Frequent computer } \\
\text { network upgrades }\end{array}$ & $\begin{array}{l}\text { Continuous } \\
\text { technological } \\
\text { development }\end{array}$ & ,220 & 66,321 & 1 & ,000 & ,469 \\
\hline
\end{tabular}

Sources: developed by the authors.

The study confirms that the sacrifice of leisure time to learn a new technology is influenced by the coercive effect of the technology, the lack of time associated with learning technological skills, the strong impact on personal life, and the time required to learn new technologies. The strong influence of technology on personal life is influenced by the lack of time relating to the acquisition of technological skills, the sacrifice of leisure time, and the acquisition of new technologies. Furthermore, it can be stated that the relationship between the coercive effect of the technology and the complexity of understanding the new technology is significant, as the significance value is less than 0.05 .

In addition, the research confirms that the threat posed by employees influences the time of acquisition of new technologies. A significant relationship could be discovered between constantly changing software, continuous technological development, and practical computer network modernization.

Based on the findings and the theoretical model, the following statements could be made: if technology forces employees to do more work than they can handle, they feel they do not have enough time to learn and develop their technological skills, or they feel that technology embedding itself in their personal lives greatly influences the sacrifice of their free time to keep up to date with said new technology. If employees need longer to understand and use new technology, it also influences how much leisure time is sacrificed. If technology is embedding itself in their personal lives, they may not have enough time to learn and develop their technological skills if they have to sacrifice their holidays and weekends to keep up to date. The coercive effects of technology and sapping away leisure time greatly affect employees in terms of the degree to which it is difficult for them to understand and use the new technology. The results further demonstrate that the sense of threat posed by employees due to newer technological skills impacts the timing of the acquisition of new technologies. In the case of constantly exchanged software within the institution, continuous technological development and frequent computer network upgrades play an important and influential role. The latter also has a great impact on the occurrence of frequent computer upgrades. Figure 2 presents the formulated findings in the model relationship system. 
A., Bencsik, B., Csinger. Innovations in Human Resources Management of Higher Education Institutions: Technostress Factors

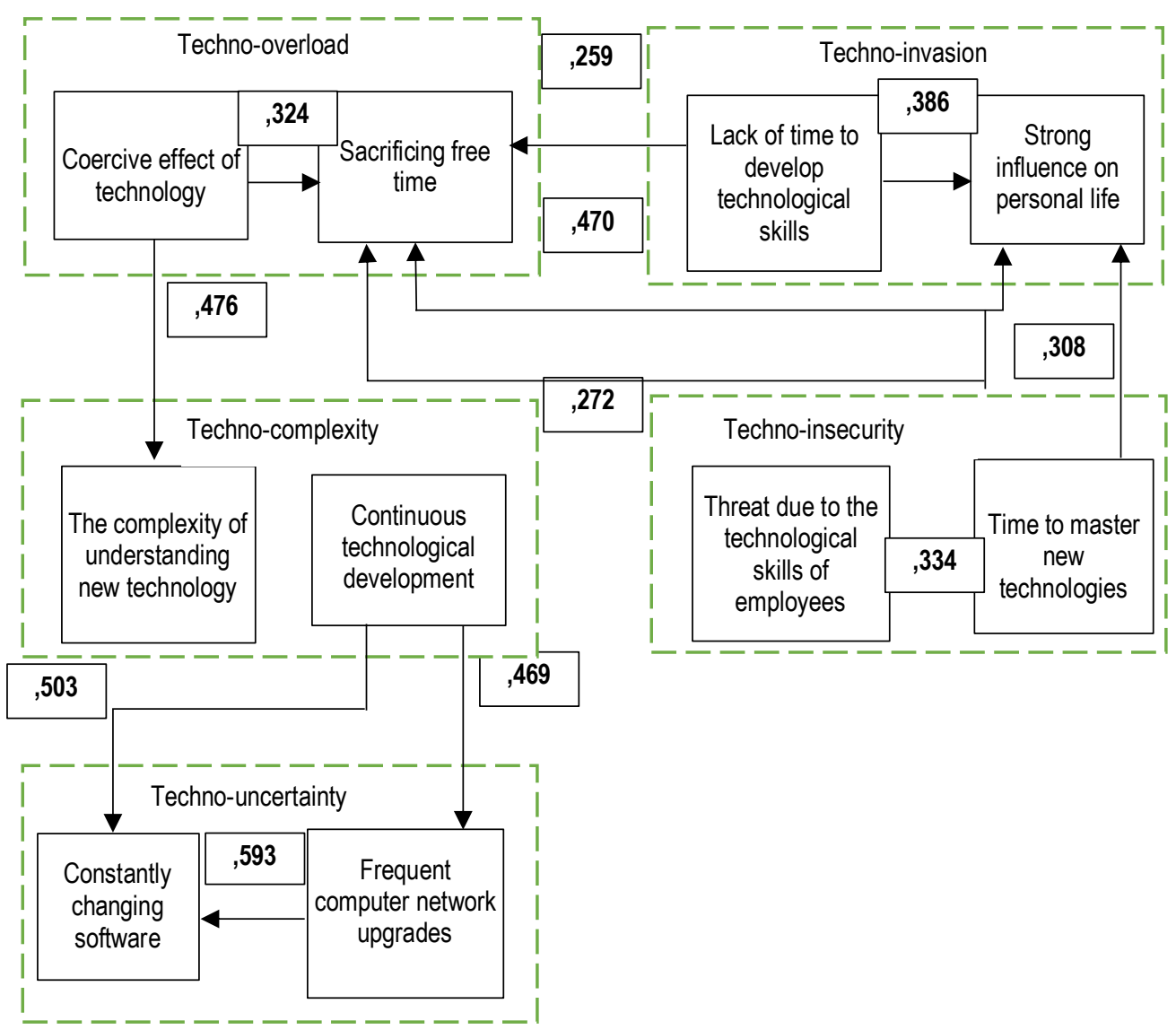

Figure 2. Influencing effects of technostress constituents

Sources: developed by the authors.

The results confirmed the formulated hypotheses, as the significance value of the variables formulated in the hypotheses is less than 0.05 . As a result, this null hypothesis, which does not assume a relationship between the variables examined, is rejected. The alternative hypothesis comes into effect. The coercive effect of technology is significantly related to the complexity of understanding new technology, resulting in a relationship between techno-overload and techno-complexity. Based on the results, techno-overload and techno-invasion also influence each other. There is a significance between the strong influence of technology on the personal life and the sacrifice of leisure time. The influence on personal life is also influenced by the time required to master new technologies, which results in a link between technoinvasion and techno-insecurity. The timing of the acquisition of new technologies has an impact not only on personal life but also on the sacrifice of leisure time, which suggests that techno-insecurity is related to techno-overload. In the last hypothesis, the authors thought to discover a link between techno-complexity and techno-unpredictability, as continuous technological development within the organization is significantly related to constantly changing software. Based on the results, the hypotheses cold be accepted. The results confirm that all of the technostress components are related to each other in terms of higher education. In the 21st century, the constant change in technology and its ever-increasing role in the workplace create fear and stress in educators. According to Jena (2015), there is an overlap between 
continuous technological developments, workload, changes in work patterns, continuous development of technological knowledge and skills, and higher expectations. As a result, further research directions in the field of technostress have been outlined. Although the topic is most often associated with job satisfaction, performance, attitudes to technology, and work efficiency, in the present study, the authors present new findings to those interested in work as well as colleagues in higher education. In the study (Coklar et al., 2017), the time required is significantly related to the strong influencing effect of technology on the personal life and the sacrifice of an individual's leisure time. Besides, Coklar et al. (2017) concluded that integrating technology into education (one of the most significant concomitants of which is technostress) is greatly influenced by educators 'technological skills, knowledge, time to learn new technology, workload, and attitude to technology. These statements are confirmed in the present research. Based on the results, the individual technostress creators are related to each other in terms of higher education. The sample examined was not representative, as a result of which it cannot be generalized. Nowadays, technostress is part of the education system, even if its manifestations are different. Failure to do so can have serious consequences. The goal is to reduce the degree of influence of creators, which would also reduce technostress. The results will be truly visible if the economic consequences of technostress for higher education can be quantified.

Conclusions. The study presented the results of research conducted in 2020 in higher education institutions. Based on the results, the hypotheses formulated during the study for the examined sample were accepted. The analysis revealed that techno-overload affects techno-complexity, as the coercive effect of technology affects the complexity of understanding new technology. The sacrifice of leisure time is influenced by the lack of time relating to the development of technological skills. There is a two-way relationship between the sacrifice of leisure time and the strong influence of technology on personal life. The technostress component of the third study, techno-insecurity, affects techno-invasion on the one hand and techno-overload on the other, as the timing of the acquisition of new technologies influences the strong influence on the personal life and the sacrifice of leisure time. The results also confirmed that technocomplexity affects techno-uncertainty, as continuous technology development influences ever-changing software and frequent computer network upgrades. Based on the outcomes, the research question could also be answered, based on which the following statements could be made:

- Techno-overload has an effect on techno-complexity as well as techno-invasion.

- Techno invasion affects techno-overload.

- Techno-complexity affects techno-uncertainty.

- Techno-insecurity affects techno-invasion.

The research results could help higher education institutions study technostress in teachers' lives, which is critical to maintaining the well-being of teachers. It contributes to the development of an appropriate higher education agenda. The authors see the possible future directions of the research primarily by expanding the subjects of research and involving countries with different geographical locations in researching at the international level.

Author Contributions: conceptualization, A. B. and B. CS.; methodology, A. B.; software, B. CS.; validation, A. B.; formal analysis, B. CS.; investigation, B. CS.; resources, A. B.; data curation, A. B.; writing-original draft preparation, B. CS.; writing-review and editing, A. B.; visualization, B. CS.; supervision, A. B.; project administration, A. B.

Funding: This research received no external funding. 
A., Bencsik, B., Csinger. Innovations in Human Resources Management of Higher Education Institutions: Technostress Factors

\section{References}

Ahmad, U. N. U., Ami, M. S., \& Ismail, W. K. W. (2012). The relationship between technostress creators and organizational commitment among academic librarians. Procedia - Social and Behavioral Sciences, 40, 182-186. [Google Scholar] [CrossRef]

Al-Ansari, M. A., \& Aalshare, K (2019). The impact of tehcnostress components on the employees satisfaction and perceived performance: The case of Quatar. Journal of Global Information Management, 27(3), 65-86. [Google Scholar] [CrossRef]

Al-Fudahir, M., \& Mellar, H. (2008). Investigatin teacher stress when using technology. Computers \& Education, 51(3), 1103 1110. [Google Scholar] [CrossRef]

Arnetz, B. B. \& Wiholm, C. (2006). Stress management and musculoskeletal disorders in knowledge workers: the possible mediating effects of stress hormones. Advances in Physiotherapy, 8(1), 5-14. [Google Scholar]

Boonjing, V., \& Chanvarasuth, P. (2017). Risk of overusing mobile phones technostress effect. Procedia Computer Science, 111, 196-202. [Google Scholar] [CrossRef]

Chen, L., \& Muthttacharoen, A. (2016). An empirical investigation of the consequences of technostress: Evidence from China Information Resources Management Journal, 29(2), 14-36. [Google Scholar] [CrossRef]

Coklar, N. A., Efilti, E., \& Şahin, L. Y. (2017). Defining teachers' technostress levels: A scale development. Journal of Education and Practise, 8(21), 28-41. ISSN 2222-288X. [Google Scholar]

Coklar. N. A., Efilti, E., Şahin, L. Y. \& AkCay, A. (2016). Investigation of techno-stress levels of teachers who were included in technology integration processes. TOJET: The Turkish Online Journal of Educational Technology, 1331-1339. [Google Scholar]

Jena, K. (2015). Technostress in ICT enabled collaborative learning environment: An empirical study among Indian academican. Computers in Human Behavior, 51, 1116-1123. [Google Scholar] [CrossRef]

La Torre, G., De Leornadis, V., \& Chiappetta, M. (2020). Technostress: how does it affect the productivity and life of an individual? Results of an observational study. Public Health, 189, 60-65. [Google Scholar] [CrossRef]

Li, B., \& Wang, X. (2019). Technostress among university teachers in higher education: A study using multidimensional personenviroment misfit theory. Frontiers in Psychology, 10,1-13. [Google Scholar] [CrossRef]

Li, L., \& Wang, X. (2020). Technostress inhibitors and creators and their impacts on universtiy teachers' work performance in higher education. Cognition, Technology \& Work, 23, 315-330. [Google Scholar] [CrossRef]

Maier, C., Laumer, S., Wirth, J., \& Weitzel, T. (2019). Technostress and the hierarchical levels of personality: a two-wave study with multiple data samples. European Journal of Information Systems, 28(5), 496-522. [Google Scholar] [CrossRef]

Ozgur, H. (2020). Relationship between teachers' technostress, technological pedagogical content knowledge (TPACK), schoo support and demographic variables: A structural equation modeling. Computers in Human Behavior, 112. [Google Scholar] [CrossRef]

Pirkkalainen, H., Salo, M., Tarafdar, M., \& Makkoken, M. (2019). Deliberate or Instinctive? Proactive and Reactive Coping for Technostress. Journal of Management Informational System, 36(4), 1179-1212. [Google Scholar] [CrossRef

Ragu-Nathan, S. T., Tarafdar, M., \& Ragu-Nathan, S. B. (2007). The Impact of Technostress on Role Stress and Productivity. Journal of Management Information Systems, 24(1), 301-328. [Google Scholar] [CrossRef]

Ragu-Nathan, S. T., Tarafdar, M., Ragu-Nathan, S. B., \& Tu, Q. (2008). The consequences of technostress for end users in organizations: Conceptual development and empirical validation. Information System Research, 19(4), 417-433. [Google Scholar] [CrossRef]

Ragu-Nathan, S. T., Tarafdar, M., Ragu-Nathan, S. B., \& Tu, Q. (2011). Crossing the dark side: examining the antecedents and consequences of technostress. Communications of the ACM, 54(9), 113-120. [Google Scholar] [CrossRef]

Sareen, P. (2019). Techno stress creators - An exploratory research on teaching and non teaching staff working in colleges. International Journal of Management and Humanities (IJMH), 3(9), 1-7. ISSN 2394-0913. [Google Scholar]

Saunders, C., Wiener, M., Klett, S., \& Sprenger, S. (2017). The impact of mental representations on ICT-related overload in the use of mobeile phones. Journal of Management Information System, 34(3), 803-825. [Google Scholar] [CrossRef]

Syvanen, A., Makiniemi, J. P., Syrja, S., Heikkila-Tammi, K., \& Viteli, J. (2016). When does the educational use of ICT become a source of technostress for Finnish teachers? Seminar.net - International Journal of media, technology, and lifelong learning, 12(2), 95-109. [Google Scholar]

Tarafdar, M., Tu, Q., \& Ragu-Nathan, T. S. (2010). Impact of Technostress on End-User Satisfaction and Performance. Journal of Management Information Systems, 27(33), 303-334. [Google Scholar] [CrossRef]

Thomée, S., Eklöf, M., Gustafsson, E., Nilsson, R., \& Hagberg, M. (2007). Prevalence of perceived stress, symptoms of depression and sleep disturbances in relation to information and communication technology (ICT) use among young adults-an explorative prospective study. Computers in Human Behavior, 23(3), 1300-1321. [Google Scholar]

Tu, Q., Wang, K., \& Shu, Q. (2005). Computer-related technostress in China. Communications of the ACM. 48(4), 77-81. [Google Scholar] [CrossRef] 
A., Bencsik, B., Csinger. Innovations in Human Resources Management of Higher Education Institutions: Technostress Factors

Андреа Бенчік, професор, Університет імені Яноша Шейє, Словацька Республіка; Університет Паннонії, Угорщина Бенс Сінгер, Університет імені Яноша Шейє, Словацька Республіка

Інновації в управлінні персоналом закладів вищої освіти: вплив технологічних стрес-факторів

У статті розглянуто вплив технологічних стрес-факторів на ефективність управління трудовими ресурсами у закладах вищої освіти. Авторами наголошено, що лавиноподібний розвиток інформаційних технологій спричинює нарощування кількості появи техностресів та їх сили впливу на населення, у тому числі викладачів та науковців. Результати аналізу теоретичних досліджень засвідчили, що стрімкий інформаційний потік та широке використання технологічних інструментів сприяє посиленню фрустрації, тривожності та страху серед працівників освіти. Таким чином, актуальність даного дослідження полягає у необхідності привернення уваги суспільства до загроз техностресу задля збереження здоров'я, якості життя та продуктивності на корпоративному рівні. Теоретичною основою дослідження $\varepsilon$ міжнародні напрацювання, присвячені питанням впливу технологічних стрес-факторів на ефективність управління трудовими ресурсами. Головною метою дослідження є визначення взаємозв'язку між факторами виникнення техностресу у закладах вищої освіти Угорщини. Підірунтям дослідження стали результати анкетування 237 викладачів закладів вищої освіти Угорщини. Практичну реалізацію усіх етапів даного дослідження здійснено з використанням інструментарію статистичного програмного забезпечення SPSS 22. Відповідно до мети дослідження авторами проведено лінійний регресійний аналіз. За результатами дослідження визначено п'ять головних тригерів техностресу, а саме: техно-перевантаження, техно-втручання, техноскладність, техно-безпека та техно-невизначеність. Авторами наголошено на синергетичному ефекті зазначених вище тригерів, що сприяє зростанню рівня техностресу серед викладачів закладів вищої освіти. Результати дослідження мають практичне значення для менеджменту закладів вищої освіти та можуть бути взяті до уваги для зниження рівня техностресу та його попередження.

Ключові слова: заклад вищої освіти, інформаційний потік, суспільна хвороба, вплив технологій, викладачі університетів.

Marketing and Management of Innovations, 2021, Issue 4 